\title{
INTEGRATION OF ENTREPRENEURSHIP INTO HIGHER EDUCATION (EDUCATIONAL SCIENCES) IN LITHUANIA AND LATVIA: FOCUS ON MODERN PEDAGOGICAL APPROACHES
}

\author{
Julija Melnikova \\ Klaipeda University, Lithuania \\ Jelena Zascerinska \\ Centre for Education and Innovation Research, Latvia
}

\begin{abstract}
The purpose of this article is to highlight the aspects of integration of entrepreneurship into higher education (Educational sciences) in Lithuania and Latvia. The article examines the nature of challenges for entrepreneurial teaching and explains how experience-based pedagogies can develop learning environments that replicate aspects of entrepreneurship. The article describes the empiric study, which explored 32 student and 16 university lectures' opinion on entrepreneurship in Educational sciences. The implications of the article could be useful for university educators, who seek to educate students most effectively with a real intention to become entrepreneurs.
\end{abstract}

Keywords: Educational sciences, entrepreneurship, entrepreneurship pedagogies, higher education.

\section{Introduction}

Nowadays entrepreneurship is considered to be the effective strategy for development and growth of societies since it leads to technical and innovative changes and causes economic growth as well as converts the new knowledge to modern products and services. That is very important for Lithuania and Latvia, who are currently moving towards innovation driven society model. According to Lisbon strategy for growth and employment, the important role of higher education in promoting entrepreneurial skills is now widely recognised. The article is based on the working definition provided by Gibb et al. (2013, p. 94): "Entrepreneurship in higher education is designed to empower staff and students to demonstrate enterprise, innovation and creativity in research, teaching and studying as well as pursuit use of knowledge across boundaries". 
The idea of the integration of entrepreneurship into higher education is especially relevant for Baltic countries, which have the similar historical background, transition period and traditions in higher education, and are currently seeking to re-arrange their educational systems. Moreover, the process of rapid economic convergence of European Union countries forces the higher education in Baltic countries to be competitive not only on local market but on international market as well. That means that universities in Lithuania and Latvia have to rethink their models of the preparation of the graduates, as well as of organising the study process and research work. The tendency stressed by comparative research data (Entrepreneurship in Latvia and other Baltic Countries, 2013; Entrepreneurship in Education in Baltic Sea Region, 2015) is that Lithuania and Latvia's universities and higher education system on the whole should take steps toward changing their classic role, which was merely producing knowledge towards entrepreneurship universities, which produce knowledge and create ideas and also transfer them to action in alignment with process of local, regional and international economic development.

However, it is pointed that Lithuania still lacks a clear strategy of entrepreneurship integration into higher education. The same problem has been identified in Latvia's higher education system (Entrepreneurship in higher education, especially within non-business studies. Final report of expert group, 2008). The context analysis of Baltic countries' higher education systems shows that the overall situation with the spread of entrepreneurship in higher education is generally very weak. The overall teaching of entrepreneurship in higher education is quite poor, especially within non-business and non-economic courses. In Lithuania noteworthy entrepreneurship teaching examples can be found, however higher education curricula even in business studies often lack coaching on how to start one's own business and acquire relevant skills. In Latvia entrepreneurship courses are missing in non-economic fields of study, and more generally inter-disciplinary approaches are rare. The low level of entrepreneurship-related abilities, knowledge and skills in the Lithuania and Latvia's universities has prompted the idea of current research.

The current research is focused on the integration of entrepreneurship into Educational sciences and covers various aspects of the issue (Melnikova et al, 2015; Melnikova \& Zascerinska, 2016a; Melnikova \& Zascerinska, 2016b). In many countries entrepreneurship in non-business studies is a very new issue. In Lithuania and Latvia Educational sciences like many other social sciences and humanities traditionally are considered as less practical and applied (Dombrovsky \& Ieva, 2005). Entrepreneurship subjects and creating business on them are considered less important in spite of their strong base in developing ideas. However, as recent piece of research (Melnikova \& Zascerinska, 2015) reveals, Educational sciences in Lithuania and Latvia are presently under pressure: on the 
one hand, Educational sciences are particularly conservative due their traditional mission; on the other - Educational sciences have to equally compete with other branches of science in the fields of academic achievements, research recognition and outcomes, skills of graduates, etc. In the context of Educational sciences the concept of social entrepreneurship has been emerged.

Gibbs et al. (2013) moves towards a broader societal model of entrepreneurship, which is especially important for Educational sciences. Social entrepreneurship can be classified in one of three ways: as for-profit organisations, which use their resources to creatively address social issues; as notfor-profit organisations, which help individuals establish their own small, forprofit businesses or, as not-for-profit ventures which create economic value to fund their own programmes or to create employment and training opportunities for their client populations. The model places emphasis on the values of entrepreneurship and developing entrepreneurial behaviours, attributes and skills encompassing concepts such as emotional intelligence, vision, holistic management and the ability to build trusting relationships. This scenario translates into a need to equip students with personal entrepreneurial competencies in order to design organisations of all kinds, public, private and NGO (non-governmental organisations) and to support effective entrepreneurial behaviour. Therefore the new challenge for entrepreneurship education is that it needs to address a number of personal, organisational and societal competencies. This in turns challenges educators to develop modes of teaching and learning that support the development of these competencies.

The focus of this paper is on the development of new pedagogies of entrepreneurship in Educational sciences. In order to answer the question more specifically, from educational and higher education perspectives, the empiric study on students and university teachers' opinion has to be carried out. Therefore the article seeks to answer the question - what is students and university educators' opinion on teaching of entrepreneurship in Educational sciences? The generalised tendencies in students and university teachers' samples in Latvia and Lithuania are provided. Hence the implications of the article could be useful for university educators, who seek to educate students most effectively with a real intention to become entrepreneurs. The methods used in the article are: analysis of scientific literature, analysis of empiric study data.

\section{Methodological principles of the empirical study}

The present empirical study has involved 32 students (Educational sciences, Education Management) from two universities in Lithuania $(\mathrm{N}=14)$ and Latvia $(\mathrm{N}=18)$ as well as 16 university teachers from same two universities in Lithuania $(\mathrm{N}=7)$ and Latvia $(\mathrm{N}=9)$. The informants samples were selected by means of the 
method of purposeful selection, when a researcher begins with specific perspectives in mind that he or she wishes to examine and then seeks out research participants, who cover that full range of perspectives.

The phenomenological approach to research modelling was applied. Students and teachers' cultural and educational experience was emphasized as significant for each research question (Luka et al., 2009) within the present empirical study. The group of research participants (field of study and work, etc.) was considered to be homogeneous.

The empiric study guiding question was as follows: what is students and university educators' opinion on teaching of entrepreneurship in Educational sciences?

The group discussion was selected as a method for qualitative data collection in students' sample of informants. The students' group discussion questionnaire included the following key questions:

- How do you understand the concept of entrepreneurship?

- How do you understand entrepreneurship in the field of education?

- How can entrepreneurship be taught in Educational sciences (within your study programme)?

The open question interview was selected as a method for qualitative data collection in university educators' sample of informants. The university teachers' questionnaire included the following questions:

- What is the most important field in your academic activity?

- $\quad$ Do you think entrepreneurial competencies are important for today's students?

- Do you integrate some pedagogical approaches and methods in order to develop entrepreneurship competencies of your students?

- Which problems do you face when seeking to integrate entrepreneurship aspects into subjects you teach?

- Provide your recommendations on teaching entrepreneurship in Educational Sciences.

The interpretive paradigm was used in the empirical study. The interpretive paradigm aims to understand other cultures, from the inside through the use of ethnographic methods such as informal interviewing and participant observation, and establishment of ethically sound relationships (Taylor \& Medina, 2013). The interpretative paradigm creates an environment for the development of any individual and helps them to develop their potential (Luka et al, 2009, 52). The core of this paradigm is human experience, people's mutual everyday interaction that tends to understand the subjectivity of human experience (Luka, 2007, 104). The paradigm is aimed at understanding people's activity, how a certain activity is exposed in a certain environment, time, conditions, i.e., how it is exposed in a certain socio-cultural context (Luka, 2007, 104). Thus, the interpretative 
paradigm is oriented towards one's conscious activity, and it is future-oriented (Luka, 2007, 104). Interpretative paradigm is characterized by the researcher's practical interest in the research question (Cohen et al., 2003). The researcher is the interpreter. The most popular informants' answers were generalized and presented in tables on order to show the main tendencies and visualize the information.

\section{Students opinion on teaching of entrepreneurship in Educational sciences}

Having generalized students informants' answers the following tendencies were disclosed (see table 1).

Table 1 Students' group discussion results

\begin{tabular}{|c|c|c|}
\hline Question & Lithuania & Latvia \\
\hline $\begin{array}{l}\text { 1. How do you } \\
\text { understand the } \\
\text { concept of } \\
\text { entrepreneurship? }\end{array}$ & $\begin{array}{ll}\text { - } & \text { Capacity to start own business } \\
\text { (12) } & \text { Earning money and making } \\
\text { - } & \text { profit of any activity (11) } \\
\text { - } & \text { Career challenges (8) } \\
\text { - } & \text { Ability to manage a new } \\
& \text { venture (8) } \\
\text { - } & \text { Personal competitiveness on } \\
& \text { the labour market (5) } \\
\text { - } & \text { Creating personal financing } \\
& \text { security (5) }\end{array}$ & $\begin{array}{ll}\text { - } & \text { Capacity to start own business } \\
& (18) \\
\text { - } & \text { Capacity to generate ideas for } \\
\text { new ventures (16) } \\
\text { - } & \text { Capacity to make profit (16) } \\
\text { - } & \text { Ability to respond to change } \\
& (10) \\
\text { - } & \text { Capacity to make personal } \\
& \text { career changes (7) }\end{array}$ \\
\hline $\begin{array}{l}\text { 2. How do you } \\
\text { understand } \\
\text { entrepreneurship in } \\
\text { the field of } \\
\text { education (social } \\
\text { entrepreneurship)? }\end{array}$ & $\begin{array}{ll}\text { - } & \text { Starting new venture (non- } \\
\text { profit) (14) } \\
\text { - } \\
\text { Managing social enterprises } \\
\text { - } 12 \text { Tackling some social issue (7) } \\
\text { - } & \text { Advance in career (6) } \\
- & \text { Project-based activity (6) }\end{array}$ & $\begin{array}{ll}- & \text { Starting new venture (for } \\
\text { profit or non-profit) (18) } \\
\text { - } & \text { Project activity (17) } \\
- & \text { Providing services for } \\
\text { community (12) } \\
\text { - } & \text { Recognition of social } \\
\text { problems and tackling them } \\
\text { (11) }\end{array}$ \\
\hline $\begin{array}{l}\text { 3. How can } \\
\text { entrepreneurship be } \\
\text { taught in } \\
\text { Educational } \\
\text { sciences (within } \\
\text { your study } \\
\text { programme)? }\end{array}$ & $\begin{array}{ll}\text { - } & \text { Lectures by entrepreneurs } \\
& (14) \\
\text { - } & \text { Discussions with business } \\
\text { development experts (13) } \\
\text { - } & \text { Support from academic staff } \\
& (10) \\
- & \text { Visits to companies (10) } \\
- & \text { Creating business plans (10) }\end{array}$ & $\begin{array}{ll}- & \text { Discussions with } \\
& \text { entrepreneurs (18) } \\
- & \text { Consultations of business } \\
& \text { development experts (18) } \\
- & \text { Visits to companies (17) } \\
- & \text { Internship in companies (11) } \\
- & \text { Coaching on business } \\
& \text { management issues }(9)\end{array}$ \\
\hline
\end{tabular}


Both Lithuanian and Latvian students understand the concept of entrepreneurship, its importance in nowadays world. Research participants emphasized that entrepreneurship is first of all about starting new venture and developing personal business. Entrepreneurship, according to informants' mind, is needed for career goals and changes in career path. As Lithuanian as Latvian students pointed that entrepreneurship is related to financial income and profit.

Both Lithuanian and Latvian students would like to get more information about entrepreneurship in the field of education and social entrepreneurship in general. Nevertheless, informants stressed that in the field of education there are a lot of opportunities to start own venture. However, research participants stressed that they lack knowledge on how to establish organisation (for profit or non-profit and what is the difference between them), how to manage its activity. Therefore respondents wished to have consultations with business development experts on the issues of establishment of organisation, budget management, administration etc. Moreover, students expressed the demand for project management competences.

Both Lithuanian and Latvian research participants emphasized that entrepreneurship is not being developed sufficiently during their studies. They expressed a wish for more practice-oriented teaching methods. Moreover, students wished to be given lectures by successful local entrepreneurs, i.e. owners of for-profit or non-profit public organisations as well as enterprise development experts (lawyers, financial managers, etc.). Respondents mentioned that visits to start up companies would be very useful. They would like to take part in seminars organized by Business incubators, Science and technology parks etc. Research participants emphasized that during the study process they would be interested in creating business plans with the support of academic staff and successful entrepreneurs. They would like to get comments on their business plans form practising business development experts in order to make their plans more feasible. They would also like to get practical experience and tools for starting their own business. Creating a business plan would have resulted in students being enthusiastic and highly motivated. Practice-based pedagogies would give them the empowering experience needed for developing entrepreneurial skills.

Research participants demonstrated high interested in the issue of entrepreneurship. Both Lithuanian and Latvian students expressed a certain need for more information about entrepreneurship in general and social entrepreneurship in particular. Informants stressed that they would like to learn more about the opportunities to start own ventures (no matter for-profit or nonprofit) in the field of education. Therefore during the study process they would like to get practical experience and tools for starting their own business. The most valuable approaches - lectures by experiences entrepreneurs, consultations by business development experts - were mentioned as in Lithuania as in Latvia. 


\section{University teachers' opinion on teaching of entrepreneurship in Educational sciences}

The results of university educators' interview answers are presented in table 2.

Table 2 University teachers' interview results

\begin{tabular}{|c|c|c|}
\hline Question & Lithuania & Latvia \\
\hline $\begin{array}{l}\text { 1. What is the most } \\
\text { important field in } \\
\text { your academic } \\
\text { activity? }\end{array}$ & $\begin{array}{l}\text { - Organizational issues of the } \\
\text { educational process } \\
\text { (preparing programmes and } \\
\text { materials, giving lectures and } \\
\text { working with students, etc.)" } \\
\text { (6) } \\
\text { - Management of the } \\
\text { educational process (planning } \\
\text { of teaching hours, } \\
\text { consultations, assessment } \\
\text { system etc.) (5) }\end{array}$ & $\begin{array}{l}\text { - } \begin{array}{l}\text { Organization of the } \\
\text { educational process } \\
\text { (planning, organizing, }\end{array} \\
\text { leading and assessing) (8) } \\
\text { - } \begin{array}{l}\text { Preparation of methodical } \\
\text { material (8) }\end{array} \\
\text { - } \\
\text { Preparation and improvement } \\
\text { of educational programmes; } \\
\text { - } \text { Implementation of } \\
\text { assessment system (6) }\end{array}$ \\
\hline $\begin{array}{l}\text { 2. Do you think } \\
\text { entrepreneurial } \\
\text { competencies are } \\
\text { important for today's } \\
\text { students? }\end{array}$ & $\begin{array}{ll}\text { - } & \text { Very important (7) } \\
\text { - } & \text { Should be a part of any } \\
& \text { subject or course (6) } \\
\text { - } & \text { Will attract more students (6) } \\
\text { - } & \text { Will promote better } \\
& \text { employment (6) } \\
\text { - } & \text { Will increase the satisfaction } \\
& \text { with studies (5) }\end{array}$ & $\begin{array}{ll}\text { - } & \text { Of a major importance (9) } \\
\text { - } & \text { Would raise the attraction of } \\
\text { study programmes }(8) \\
\text { - } & \text { Will equip students with } \\
\text { today relevant and necessary } \\
\text { competencies }(7) \\
\text { - } \quad \text { Will increase the satisfaction } \\
\text { with studies (7) } \\
\text { - Will bridge the needs of } \\
\text { labour markets with } \\
\text { university programmes }(7)\end{array}$ \\
\hline $\begin{array}{l}\text { 3. Do you integrate } \\
\text { some pedagogical } \\
\text { approaches and } \\
\text { methods in order to } \\
\text { develop } \\
\text { entrepreneurship } \\
\text { competencies of } \\
\text { your students? }\end{array}$ & $\begin{array}{ll} & \text { Include some active-learning } \\
\text { methods (6) } \\
\text { - } & \text { Apply project activity (6) } \\
\text { - } & \text { Foster collaboration and } \\
\text { group work (6) } \\
\text { - } & \text { Arrange visits to } \\
\text { organizations } \\
\text { - } & \text { Invite practitioners form } \\
\text { organizations to share } \\
\text { experience (5) }\end{array}$ & $\begin{array}{ll}\text { - } & \text { Foster project activity (6) } \\
\text { - } & \text { Organize visits to institutions } \\
& (6) \\
\text { - } & \text { Cooperate with schools, } \\
& \text { community partners (5) } \\
- & \text { Improve study modules with } \\
& \text { newest pedagogies and } \\
\text { technologies (5) }\end{array}$ \\
\hline $\begin{array}{l}\text { 4. Which problems } \\
\text { do you face when } \\
\text { seeking to integrate } \\
\text { entrepreneurship } \\
\text { aspects into subjects } \\
\text { you teach? }\end{array}$ & $\begin{array}{ll}\text { - } & \text { Lack of modern knowledge } \\
& (6) \\
- & \text { Lack of methodological } \\
\text { support (6) } \\
\text { - }\end{array}$ & $\begin{array}{l}\text { - Lack of competencies how to } \\
\text { teach entrepreneurship (6) } \\
\text { - Lack of knowledge how to } \\
\text { assess students' } \\
\text { competencies in } \\
\text { entrepreneurship (6) }\end{array}$ \\
\hline
\end{tabular}


Julija Melnikova, Jelena Zascerinska. Integration of Entrepreneurship into Higher Education (Educational Sciences) in Lithuania and Latvia: Focus on Modern Pedagogical Approaches

\begin{tabular}{|c|c|c|}
\hline & $\begin{array}{l}\text { the field of entrepreneurship } \\
\text { (6) }\end{array}$ & \\
\hline $\begin{array}{l}\text { 5. Provide your } \\
\text { recommendations on } \\
\text { teaching } \\
\text { entrepreneurship in } \\
\text { Educational } \\
\text { Sciences. }\end{array}$ & $\begin{array}{ll}\text { - } & \text { Carry out research on } \\
\text { university academic staff } \\
\text { needs (5) } \\
\text { - } & \text { Arrange training sessions (4) } \\
\text { - } & \text { Invite experienced lecturers } \\
& \text { (4) }\end{array}$ & $\begin{array}{l}\text { Organize training events on } \\
\text { how to teach } \\
\text { entrepreneurship in non- } \\
\text { business studies (5) }\end{array}$ \\
\hline
\end{tabular}

University teachers in Lithuania identified the field of organization and management of the educational process as the most important in their professional activity. Latvian educators named organization of the educational process, preparation of educational programs, and preparation of methodological materials as the most important professional activities. When describing their professional activity informants mentioned that they face various problems in it. Some problems are presupposed by the complex factors that are presently affecting higher education as a system nationwide (decreasing number of students, low salaries, etc.). Other problems are more methodical, daily, resulting in professional activities (students' low motivation to study, poor attendance rates, lack of technological support, etc.).

Both Lithuanian and Latvian university teachers, who took part in the interview, argued that entrepreneurship should be integrated into study subjects in order to develop students' entrepreneurial competencies. In their opinion, integration of entrepreneurship would make studies more attractive and possibly more beneficial for students. Study participants argued, that modern young people are focused more on pragmatic issues (such as: opportunities to earn money, create some venture etc.) then on academic knowledge. Therefore, to their mind, universities should advertise themselves widely as being entrepreneurial and inform all the stakeholders that entrepreneurship competencies are highly rated and emphasized during the study process. That would attract more students to enter universities on the whole and Educational Sciences in particular.

However, study participants also pointed out that they face some important problems when they seek to integrate entrepreneurship competencies development methods and pedagogies in to subjects they teach. Lithuanian informants argued that they lack methodological support and updated methodological tools in integrating entrepreneurship into educational process. They also noted that when working with different learning needs they feel the lack of knowledge of the methods outlined. Latvian educators recognized the lack of their own knowledge on how to effectively develop students' entrepreneurial competencies because they have not had any trainings on that that. In addition, the research participants mentioned that in the activity of modern university educators has undergone a lot of changes recently, they have to face new 
challenges such as: entrepreneurship itself, satisfaction of stakeholders' needs, empowerment of learners', application of modern technological tools and so on. This requires new knowledge and skills. In this context, it is important to have relevant methodological source of support, and the latest source of modern knowledge, theories and experiences. Because of the fact that respondents', who took part in the study, age is more than 50 years, it could have had some effect on the outcomes of the study. Such an assumption is made on the basis of PIAAC survey results, which shows that skills of problem solving using technology in this age group are lower than those of younger adults.

Study participants both from Latvia and Lithuania have provided some recommendations on effective integration of entrepreneurship into Educational Sciences. First, they emphasized the need for coherent and continuous research on university educators' needs and demands as well as competencies in order to provide them opportunities for self-education, professional support, assistance tools, etc. thus solving the problem of insufficient professional support. Secondly, having in mind some special needs of some specific groups of university educators (e.g. technology skills, foreign languages, management, cross-cultural cooperation, change management and other competence) it is appropriate to provide certain information, educational and organizational assistance to them. For this reason, it is reasonable to organize training for different groups of university educators with respects to their certain needs. Moreover, it is recommended to invite experienced adult education lecturers to these seminars, who can share their experiences how to teach entrepreneurship especially in nonbusiness studies.

Summarizing the interview results it could be said the university teachers both in Latvia and Lithuania recognize the demand for integration of entrepreneurship into study process. The development of students; entrepreneurship competencies should become a priority when organizing and managing educational process. That would help to improve the quality of studies as well as to raise students' satisfaction with the studies. However educators themselves feel the need for relevant knowledge and professional support on how to apply entrepreneurship development methods especially in non-business studies. Therefore there is a need for courses and seminars for university academic staff in Latvia and Lithuania.

\section{Implications}

Lithuania and Latvia need a coherent model of integration of entrepreneurship into Education sciences, however, the model cannot be just copied from some other European Union country due to: Baltic countries have certain traditions in higher education that are presupposed by historical 
background and transition period; entrepreneurship in non-business studies, especially in Education sciences is a new issue for all European Union countries; in Baltic countries Education sciences are currently under pressure and are forced to change their conservative purpose and compete with other branches of science in research, preparation of graduates, arrangement of study process etc.

Experiential learning has risen to the forefront of entrepreneurship education, as universities respond to research that encourages both real-world projects and extracurricular learning activities to better teach entrepreneurship, such as internships, business plan competitions etc. Therefore the methods of experiential learning could become a basis for developing entrepreneurship teaching pedagogies in Educational sciences. Education for and in enterprise provides students with a learning environment that would support them in their endeavour.

Research participants demonstrated high interested in the issue of entrepreneurship. Both Lithuanian and Latvian students expressed a certain need for more information about entrepreneurship in general and social entrepreneurship in particular. Informants stressed that they would like to learn more about the opportunities to start own ventures (no matter for-profit or nonprofit) in the field of education. Therefore during the study process they would like to get practical experience and tools for starting their own business. The most valuable approaches - lectures by experiences entrepreneurs, consultations by business development experts - were mentioned as in Lithuania as in Latvia.

Summarizing the interview results it could be said the university teachers both in Latvia and Lithuania recognize the demand for integration of entrepreneurship into study process. The development of students; entrepreneurship competencies should become a priority when organizing and managing educational process. That would help to improve the quality of studies as well as to raise students' satisfaction with the studies. However educators themselves feel the need for relevant knowledge and professional support on how to apply entrepreneurship development methods especially in non-business studies. Therefore there is a need for courses and seminars for university academic staff in Latvia and Lithuania.

\section{References}

Gibb, A., Haskins, G., \& Robertson, I. (2013). Leading the entrepreneurial university: Meeting the entrepreneurial development needs of higher education institutions. Universities in Change, 9-45. New York: Springer.

Dombrovsky, V., \& Ieva, U. (2005). Entrepreneurship in Latvia. Telia Sonera Institute Discussion Paper No. 2, Stockholm School of Economics in Riga, Latvia. 
Cohen, L., Manion, L., \& Morrison, K. (2003). Research Methods in Education. Routledge Education, 2003, 414 p. Retrieved 28/11/2015 from http://www.routledge.com/ textbooks/9780415368780/e/ch26.asp.

Entrepreneurship in Education in Baltic Sea Region (2015). Retrieved 28/11/2015 from http://socialinnovation.lv/en/educational-materials-of-social-entrepreneurshipdevelopment-in-the-baltic-sea-region/

Entrepreneurship in higher education, especially within non-business studies (Final report of expert group), (2008). Retrieved 28/11/2015 from http://www.koda.ee/public/ entr_highed.pdf

Entrepreneurship in Latvia and Other Baltic States: Results from the Global Entrepreneurship Monitor (2013). Retrieved 28/11/2015 from http://freepolicybriefs.org/2013/11/04/ entrepreneurship-in-latvia-and-other-baltic-states-results-from-the-globalentrepreneurship-monitor/

Luka, I. (2007). Students and the educator's co-operation as a means of development of students' ESP competence. Paper presented at the European Conference on Educational Research, University of Goteborg, 10-12 September 2008. The document was added to the Education-line collection on 18 July 2008. British Education Index data base. ID $172916 \mathrm{http} / /$ www.leeds.ac.uk/educol/documents/172916.htm

Luka, I., Ludborza, S., \& Maslo, I. (2009). Effectiveness of the use of more than two languages and quality assurance in European interuniversity master studies. Paper presented at the European Conference on Educational Research, University of Vienna, September 28-30, 2009.

Melnikova, J., Zaščerinska, J., \& Glonina, O. (2015). A Conceptual Framework on Entrepreneurship Education in Vocational Teachers Training. Proceedings of Riga Teacher Training and Educational Management Academy's 10th International Young Scientist Conference, pp. 60-69. Riga: Riga Teacher Training and Educational Management Academy, 137 p.

Melnikova, J., \& Zaščerinska, J. (2016). Integration of Entrepreneurship into Higher Education (Educational Sciences) in Lithuania and Latvia: Focus on Students' Entrepreneurial Competencies. Journal of Social Sciences Regional Formation and Development Studies. No. 1 (18), pp. 100-109. Klaipeda: Klaipeda University Social Sciences Faculty. DOI: 10.15181/rfds.v18i1.1250.

Melnikova, J., \& Zaščerinska, J. (2016). Entrepreneurship in Education Sciences in the Baltic Countries: Mezzo-Level Context Analysis. Proceedings of the 17th Student and Teacher Scientific and Practical Conference National Economy Development: Problems and Solutions, 28 May, 2015, pp. 22-26. Rēzekne, Latvia: Rēzeknes Tehnologiju akadēmijas Izdevniecība 2015. ISBN 978-9984-44-187-0.

Taylor, P. C., \& Medina, M. N. (2013). Educational research paradigms: from Positivysm to multiparadigmatic. Journal of Meaning-Centered Education, 1. Retrieved 28/11/2015 from http://www.meaningcentered.org/journal/volume-01/educational-researchparadigms-from-positivism-to-multiparadigmatic/ 